\title{
KOMUNIKASI POLITIK DALAM PEMILIHAN KALEBUN DI DESA SANATENGAH KECAMATAN PASEAN KABUPATEN PAMEKASAN
}

\author{
Sudahri, S.Sos., M.I.Kom \\ Prodi Ilmu Komunikasi Fakultas Ilmu Sosial dan Ilmu Politik \\ Universitas Muhammadiyah Jember \\ sudahriumj@yahoo.co.id
}

\begin{abstract}
Pilkades as a venue for political consolidation at the village level provides an educating political education. Residents are openly confronted with prospective "Kalebun" (village heads). The interesting thing to study in the implementation of Pilkades is the stage of the campaign where each candidate "Kalebun" competes to introduce himself, give promises, approach the village community, and several other approaches through the communication process, both directly carried out by the candidates "Kalebun "or by the successful team. This study aims, among others: To describe the role of political communication carried out by "Kalebun" candidates in winning elections; the form of communication carried out; obstacles faced in political communication with villagers in an effort to win the election of the "Kalebun" and the response of the village community. This type of research uses a qualitative descriptive research method. The target of this research is the selected "Kalebun" candidates and "Kalebun" candidates who lose the following with their successful team and the community as voters. Data collection uses an interview or interview method and a purposive sampling method.
\end{abstract}

Keywords: Political communication, "kelebun", village elections

\begin{abstract}
Abstrak
Pilkades sebagai ajang konsolidasi politik di tingkat desa memberi pendidikan politik yang mencerdaskan. Warga secara terbuka dihadapkan dengan bakal calon Kalebun (kepala desa). Hal yang menarik untuk dikaji dalam pelaksanaan Pilkades adalah tahapan kampanye dimana masing-masing calon Kalebun berlomba-lomba memperkenalkan diri, memberikan janji-janji, melakukan pendekatan dengan masyarakat desa, dan beberapa pendekatan lainnya melalui proses komunikasi baik dilakukan secara langsung oleh calon Kalebun maupun oleh tim suksesnya. Penelitian ini bertujuan, antara lain : Untuk mendeskripsikan peranan komunikasi politik yang dilakukan oleh calon Kalebun dalam memenangkan pemilu; bentuk komunikasi yang dilakukan; kendala-kendala yang dihadapi dalam komunikasi politik dengan warag desa dalam usaha memenangkan pemilihan Kalebun tersebut dan tanggapan masyarakat desa. Jenis penelitian menggunakan metode penelitian deskriptif kualitatif. Sasaran penelitian dalam hal ini adalah calon Kalebun terpilih dan calon Kalebun yang kalah berikut dengan tim suksesnya serta masyarakat selaku pemilih. Pengumpulan data memakai metode wawancara atau interview dan Metode purpossive sampling.
\end{abstract}

Kata Kunci : Komunikasi politik, kelebun, pemilu desa 


\section{Pendahuluan}

Kalebun adalah sebutan dalam bahasa madura terhadap seorang kepala desa, sebagaimana kepala desa yang terjadi di penjuru nusantara Kalebun juga memiliki fungsi dan peran sama seperti kepela desa kebanyakan, Kalebun yang terpilih harus mengikuti aturan kenegaraan yang ada di pemerintahan Indonesia. Dalam fungsi yang lain Kalebun juga bertanggungjawab dalam menumbuhkembangkan nilai-nilai swadaya dan gotong royong di masyarakat. Dengan ini, sangat penting sebuah desa dipimpin oleh Kalebun yang baik dan dipilih secara jurdil oleh rakyatnya.

Dalam suatu kampanye pemilihan Kalebun, setiap calon Kalebun yang bertarung diperkenankan untuk memperkenalkan diri, menyampaikan visi dan misinya dalam program pembangunan desa dan melakukan upaya untuk memenangkan pemilihan Kalebun sebagaimana dalam peraturan perundangundangan yang berlaku. Dengan komunikasi yang tepat dan efektif, diharapkan seseorang mampu "menampilkan diri" dalam masa kampanye tersebut untuk menarik simpati masyarakat desa. Dalam upaya menarik simpati massa tersebut diperlukan strategi komunikasi yang tepat.
Komunikasi yang dilakukan oleh calon Kalebun disadari atau tidak akan sangat berpengaruh pada hasil pemungutan suara pemilihan Kalebun. Untuk memenangkan pemilihan Kalebun diperlukan strategi komunikasi yang baik yang dilakukan oleh calon Kalebun berikut tim suksesnya. Dengan komunikasi yang baik dengan warga desa tentunya target untuk memenangkan pemilihan Kalebun dapat terwujud dengan baik. Namun demikian, siapa yang terpilih adalah siapa yang berhasil mengimplementasikan komunikasi politik nya dengan baik dalam arti mampu untuk memaksimalkan segala kelebihan pribadinya secara personal dan menutupi kekurangannya.

\section{Metode}

Jenis penelitian ini adalah deskriptif kualitatif yang menggunakan pendekatan fenomenologi. Metode kualitatif adalah cara penelitian yang akan memperoleh data deskriptif dalam bentuk kata-kata tertulis atau lisan dari informan dan dari perilaku yang dapat diamati. Sedangkan deskriptif bertujuan untuk melukiskan secara sistematis fakta atau karakteristik populasi tertentu secara faktual dan cermat. (Isaac dan Michael dalam Rakhmad, 1991 : 22). 
Teknik dan metode pengumpulan data, penulis akan menggunakan metode wawancara atau interview, Yang dibutuhkan dalam hal ini adalah data primer dan data skunder. Data primer diperoleh dari pengumpulan informasi dari informan kunci dan pengamatan terhadap realitas lapang, yang dilengkapi dengan pedoman wawancara. Dan data sekunder merupakan data yang digunakan untuk mendukung perolehan dari data primer. Data lapangan yang diperoleh dari interview secara langsung dengan para informan sebagai informasi atau data yang mencakup tentang interaksi antara komponen komunikasi yang terjadi dalam proses komunikasi, baik secara verbal dan non verbal.

\section{Pembahasan}

\section{Bentuk Komunikasi Yang Dilakukan} Oleh Calon Kalebun Dalam Memenangkan Pemilihan Kepala Desa.

Calon Kalebun (kepala desa) yang berkompetisi dalam pemilihan disosialisasikan kepada masyarakat baik melalui pamflet, baliho ditempat-tempat yang terbuka maupun secara formal dalam kegiatan-kegiatan kemasyarakatan. Dari sekian proses dan mekanisme dalam pemilihan Kalebun tersebut, yang paling menarik untuk dibahas sekaligus dikaji dalam pembahasan penulisan penelitian adalah masa kampanye. Dalam masa kampanye, dapat dilihat bagaimakah upaya-upaya yang dilakukan oleh para kandidat calon Kalebun untuk merebut hati dan simpati para warga desa agar kelak saat hari " $H$ " pemilihan, mereka mau mencoblos atau memilihnya dan terpilih menjadi Kalebun. Dalam masa kampanye tersebut pula dapat kita lihat bagaimanakah mesin-mesin politik calon Kalebun bekerja untuk menjalankan roda kampanye agar sampai ke tujuan ; yaitu dapat sukses dalam pemilihan kelak. Masa kampanye merupakan masa yang penting calon Kalebun untuk "berkomunikasi" dengan warga masyarakat selaku pemilih.

Untuk memudahkan komunikasi tersebut, para calon Kalebun melakukan banyak strategi komunikasi politi dengan dibantu oleh tim sukses dalam mengawal proses pemilu dan pemenangan. Dalam pelaksanaan kampanye tersebut terjadi pula komunikasi politik antar kekuatan politik dalam rangka menguatkan basisbasis dukungan yang menyeluruh diseluruh lapisan masyarakat.

Selain kampanye yang bersifat dialogis tersebut, mamsing-masing calon Kalebun juga menggelar open house yang sangat kental sekali dengan budaya money politics atau politik uang. Dalam hal ini 
para calon Kalebun membuka diri dengan membuka pintu rumah mereka dari kunjungan warga masyarakat desa yang memberikan dukungan kepada mereka. Biasanya selain memberi,kan dukungan secara langsung secara lisan, warga masyarakat yang berkunjung akan diberikan jamuan berupa makanan dan minuman, saat pulang akan diberi amplop sebagai "sangoh" (dalam bahasa Indonesia = uang saku) yang jumlahnya bervariasi.

Berdasarkan gambaran tersebut di atas komonikasi interpersonal yang dijalankan oleh para calon Kalebun melalui 2 jalan yaitu secara formal dan non-formal dengan gambaran sebagai berikut :

1). Secara formal, pelaksanaan komunikasi politik tersebut adalah melalui kampanye secara terbuka yang dilaksanakan secara resmi melalui kampanye dialogis, kampanye monolog, dan kampanye melalui acara pengajian. Dalam hal ini para calon secara resmi menyampaikan visi dan misinya dalam pembangunan desa. Diperlukan kemampuan intelektual dan berkomunikasi melalui paparan visi dan misi sehingga dapat mempengaruhi masyarakat dalam memberikan pilihan. Kampanye secara formal ini adalah kampanye cerdas yang sangat baik bentuknya karena tidak saja pemimpinnya yang cerdas namun warga masyarakatnya juga harus cerdas untuk menilai, menimang, menimbang dan nantinya memberikan suaranya dalam pemilihan. Sosok pemimpin yang baik adalah pemimpin yang mampu mewujudkan janji-janji politiknya pada upaya pembangunan desa di masa yang akan datang jika ia terpilih.

2). Secara Non Formal, kampanye nonformal dalam hal ini terselenggara melalui open house yang dilakukan oleh masingmasing calon. Komunikasi politik dalam pendekatan non-formal ini akan terasa lebih dekat dan intens, karena dilakukan secara langsung dan jumlah massa biasanya lebih sedikit sehingga bisa dilakukan dari hati-ke hati. Komunikasi non formal dalam hal ini akan lebih terasa manfaatnya karena juga diselingi dengan jamuan makanan dan kinuman ala kadarnya bahkan disertai uang amplopan sebagai uang "sangu" kepada warga yang mengunjungi rumahnya untuk sekedar pengingat agar ia memilih dirinya dalam pemilihan Kalebun nanti. Open house atau diistilahkan juga dengan silaturrahmi tersebut seharusnya dimanfatkan dengan sebaik-baiknya oleh calon Kalebun untuk berkomunikasi dengan lebih dekat dengan warga yang mengunjunginya, untuk memaparkan visi dan misinya menjadi 
Kalebun, namun budaya amplopan sebagai money politics yang sudah terlanjur berkembang dan membudaya dalam kehidupan masyarakat menjadikan komunikasi tersebut sekedar pelengkap saja. Masyarakat yang datang bersilaturrahmi dan berkunjung sekedar meminta imbalan untuk jasanya memberikan suara pada saat pemungutan suara kelak.

Demikian beberapa bentuk komunikasi yang dapat penulis inventarisasi selama masa kampanye pemilihan Kalebun. Lepas dari itu semua, strategi komunikasi yang tepat akan memberikan manfaat bagi calon kepala deesa itu sendiri. Ada atau tidaknya permainan politik uang dan budaya curang lainnya masyarakat harus cerdas dan teliti dalam memberikan pilihan suaranya, antara lain dengan benar-benar berpikir dan memberikan penilaian terhadap calon pemimpin yang berkualitas. Berikut ini beberapa papara visi dan misi masingmasing calon selama masa kampanye :

Demokrasi, di satu sisi dianggap sebagai sebuah jalan terbaik dalam penyelesaian permasalahan kekuasaan atau penyelesaian permasalahan publik lainnya. Dilain pihak dalam proses perjalanannya tidak sedikit hal-hal negatif yang ditimbulkannya. Namun demikian, semakin besar pengaruh seseorang; maka semakin besar pula kemungkinan calon Kalebun terpilih, sehingga diperlukan sosok atau figur yang baik dan dapat mengayomi desa.

Hampir setiap hari rumah calon Kalebun penuh dengan tamu. Untuk menampung tamu, depan dan samping rumah sampai dipasang peneduh terop/terpal) untuk menampung tamu yang hampir setiap hari datang secara bersamaan sampai berpuluh-puluh orang. Tidak mengherankan ada istilah yang menyebut kalau mau menjadi Kalebun harus siap-siap utuk hajatan (seperti pernikahan) sebulan penuh. Bagaimana tidak, satu bulan sebelum hari pencoblosan, calon Kalebun hampir setiap hari menerima tamu, tentunya juga harus menyediakan hidangan untuk para tamu. Sampai-sampai calon Kalebun harus menyediakan rokok dengan merek tertentu sebanyak banyaknya. Jangan heran jika merek rokoknya sejenis dan masing masing calon mempunyai merek tersendiri karena merek rokok tersebut menjadi identitas dari masing-masing calon. Tidak terbayang berapa banyak uang yang harus dikeluarkan hanya untuk menjamu tamu saja. Acara berkunjung ke calon kandidat memang suda menjadi budaya sedari dulu. 
Dalam suatu kampanye pemilihan Kalebun, setiap calon Kalebun yang bertarung diperkenankan untuk memperkenalkan diri, menyampaikan visi dan misinya dalam program pembangunan desa dan melakukan upaya untuk memenangkan pemilihan Kalebun sesuai dengan yang digariskan Dengan komunikasi yang tepat dan efektif, diharapkan seseorang mampu "menampilkan diri" dalam masa kampanye tersebut untuk menarik simpati masyarakat desa. Dalam upaya menarik simpati massa tersebut diperlukan strategi komunikasi yang tepat. Komunikasi politik yang efektif sangat dipentingkan terutama dalam hal membujuk lawan. Dalam komunika politik, calon Kalebun mencoba untuk tampil sebaik mungkin dan sekuat tenaga dalam meyakinkan masyarakat pemilih..

Kendala-Kendala Yang Dihadapi Calon Kalebun Dalam Komunikasi politik Dengan Warga Desa Dalam Usaha Memenangkan Pemilihan Kalebun Tersebut

Dalam membahas masalah pemilihan Kalebun khususnya di desa Sanatengah tidak lepas dari konflik kepentingan masing-masing calon Kalebun dengan masing-masing tim sukses berikut masyarakat yang mendukungnya ; bahkan orang-orang yang bukan warga desa yang "sengaja" menjadi orang bayaran untuk mendukung "sementara". Dalam suatu konflik melibatkan setidaknya lebih dari dua pihak dengan masing-masing kepentingan yang berbeda. Dalam perspektif sosiologis, konflik pada dasarnya merupakan salah satu bentuk dari interaksi sosial. Konflik merupakan bentuk interaksi disosiatif, yaitu kontak yang terjadi antara kedua belah pihak yang saling bertentangan atas dasar beda dukungan, dan berbagai kepentingan yang melingkupinya dan menjadi bagian penting di masyarakat. Dalam beberapa kejadian, bahwa hal seperti itu sudah ditunggangi oleh kepentingan yang lebih besar dari orang-orang yang lagi berkuasa, dibandingkan dengan dinamika dari banyak perbedaan cara pandang yang ada di masyarakat. Dan kekuasaan inilah yang sesungguhnya memainkan peranan penting dari terjadinya persinggungan antar elemin atau kelompok di masyarakat. Dalam mendekati suatu permasalahan, konflik tidak dapat dilihat sebagai permasalahan ekonomi atau kepentingan saja seperti yang biasa diungkapkan penganut teori konflik. Setidaknya faktor struktural dan kultural perlu dipertimbangkan dalam beberapa 
jenis konflik yang spesifik. Dalam menjelaskan suatu konflik, maka harus mendepenelitiankan kondisi-kondisi nyata yang menghasilkan hal itu. Karena dalam kehidupan suatu etnis permasalahan ekonomi bisa jadi yang kesekian tetapi ada hal-hal sensitif lain yang bisa memicu konflik seperti harga diri dan status. Proposisi teoritis tersebut setidaknya menjelaskan bahwa konflik itu dapat dimungkinkan dengan berbagai faktor, baik struktural maupun kultural.

Konflik personal yang terjadi antar individu karena beredarnya prasangka negatif menurut paradigma fungsional struktural dianggap hanya sebagai bentuk ketegangan dan penyimpangan. Bahwa ketegangan dan ketimpangan tersebut akan kembali ke kondisi normal karena pada dasarnya masyarakat adalah suatu sistem yang seimbang dan normal. Teori fungsional struktural dalam memandang masyarakat cenderung menekankan kepada keserasian, konformitas dan konsensus di dalam masyarakat. Kondisi equilibrium ini dimungkinkan karena adanya dua macam mekanisme yaitu mekanisme sosialisasi dan meknisme kontrol sosial. Yang pertama melibatkan bentuk-bentuk budaya seperti nilai-nilai (values), keyakinan (beliefs), adat-istiadat, bahasa, dan lain. Unsur-unsur tersebut diinternalisasikan dalam sistem personal sehingga perilaku atau tindakan individu dapat dilihat sebagai sebuah sistem sosial yang terstruktur. Sedangkan kontrol sosial melibatkan kekuasaan dan dominasi struktur sosial tertentu.

Konflik bisa mengarah pada hal yang positif atau negatif seperti dijelaskan bahwa permasalahan sosial yang menimbulkan konflik dibedakan dalam dua kategori, pertama konflik bersifat fungsional (positif) dan konflik yang bersifat disfungsional (negatif) terhadap unsur-unsur sosial di masyarakat. Konflik bersifat fungsional jika konflik tersebut dapat memperbaiki atau setidaknya mempertahankan struktur-struktur sosial yang ada. Sedangkan konflik bersifat disfungsional jika konflik tersebut menimbulkan perpecahan dan merusak struktur yang sudah ada, akhirnya dalam masyarakat tertentu, konflik yang tidak ditampakkan tidak menimulkan efek positif.

Sehubungan dengan itu konflik menjadi cerminan terhadap semangat perubahan masyarakat. Konflik juga dapat menjadi sebuah langkah dalam membentuk pola-pola interaksi dalam struktur sosial, juga dapat menjadi wujud pembeda dari sekian dimensi antara dua atau lebih kelompok. Konflik antar 
kelompok dapat memeperteguh identitas internal kelompok sekaliguas menjaga agar tidak menyatu dengan budaya yang ada di sekelilingnya. Oleh karena itu konflik ukan sesuatu yang harus di hindari apalagi ditakuti, karena konflik tidak selamanya berfungsi memecah belah atau merusak suatu hubungan. Oleh karena itu konflik tidak lagi diyakini seagai media perusak dan penyebab perpecahan. Konflik bisa menjadi alat dalam memelihara hubungan; jembatan dalam terbentuknya aliansi dengan kelompok lain; menghidupkan kembali peranan individu yang sebelumnya bersebrangan; dan juga bisa menjadi media dalam membangun komunikasi.

Perubahan sosial di dalam sistem sosial bersumber dari situasi konflik yang berakar dari keadaan dimana pihak atau kelompok tertentu yang satu berusaha mempertahankan kekuasaan dan otoritas, sedangkan pihak yang lain berusahan mendapatkan kekuasaan dan otoritas tesebut dan realitas sosial dapat digambarkan suatu putaran konflik yang tidak akan pernah berakhir dalam berbagai sistem sosial.

Pada perkembangannya, masya-rakat di desa Sanatengah terkelompok menjadi dua kelompok yang saling menjatuhkan dan saling menggalang kekuatan. Berbagai cara dilakukan untuk memengkan Pemilihan Kalebun ini. Selanjutnya atas hal tersebut terjadi keresahan dimanamana yang imbasnya adalah rakyat kecil. Imbas dari konfliknya kedua kubu ini sangat meresahkan penduduk yang tidak menahu mengenai politik dan kekuasaan yang bisanya Cuma mengikuti ajakan dari orang-orang yang berpengaruh. Dan ini menghasilkan keresahan dimana-dimana dan desa sudah tidak aman lagi dimanadimana sering terdengar penculikan ternak penduduk dan semacamnya. Sebagaimana telah disebutkan bahwasanya penyelenggaraan pemilihan Kalebun (pilkades) rentan dengan persoalan. salah sedikit dalam strategi penanganan, mudah menyulut keributan antarpendukung. namun bila "dipagari" rambu kesepakatan, konflik bisa dieliminir.

\section{Kesimpulan}

Dapat disimpulakan bahwa, komunikasi politik calon Kalebun masingmasing mempunyai kelebihan dan kekurangan pribadi yang tentunya berguna dalam menjadi pertimbangan masyarakat desa pada pelaksanaan pemilihan Kalebun bahkan menjadi hambatan tersendiri bagi calon Kalebun yang bersangkutan. Dalam hajatan pelaksanaan pemilihan Kalebun, apa yang menjadi kelebihan masing- 
masing calon secara personal lebih ditonjolkan dari pada kekurangan yang ada sebagai wujud mempengaruhi dan menarik simpati dari masyarakat desa; dengan satu tujuan yaitu bisa menang dalam pertarungan pemilihan Kalebun.

Bentuk komunikasi yang dilakukan oleh masing-masing calon antara lain dengan komunikasi secara langsung melalui kampanye dialogis maupun kampanye open house melalui jalur „silaturrahmi” pendukung ke rumah calon Kalebun dan kampanye secara tidak langsung yaitu melalui tim sukses dan melalui media kampanye berupa poster, sticker, spanduk, dan selebaran yang pada intinya mengajak penduduk untuk memilihnya pada saat pemilihan. Komunikasi tersebut kadangkala melalui kendaraan yang disebut money politics atau politik uang baik berupa pemberian uang secara langsung, pembagian sembako, pemberian materi tertentu maupun dengan mengadakan kegiatan tertentu seperti sunnatan massal dan pengajian .

Kendala-kendala yang dihadapi calon Kalebun dalam usaha memenangkan Pemilihan Kalebun Sanatengah, anatara lain, Penyelenggaraan pemilihan Kalebun (pilkades) rentan dengan persoalan. Salah sedikit dalam strategi penanganan, mudah menyulut keributan antarpendukung. Namun bila "dipagari" rambu kesepakatan, konflik bisa dieliminir. Adanya serangan fajar ; dalam hal ini masih dilakukannya kampanye dalam hari tenang serta dilakukannya politik uang pada satu hari sebelum dan pada pagi hari sebelum pencoblosan dilakukan. Serangan fajar ini dilakukan dalam upaya untuk "membeli" suara warga yang punya hak suara untuk memilih calon Kalebun tertentu. Serangan fajar ini dilakukan oleh tim sukses calon Kalebun langsung ke rumah warga pada pagi harinya atau mencegat warga yang akan mencoblos ke Tempat Pemungutan Suara (TPS) untuk memberikan amplop berisi uang.

\section{Daftar Pustaka}

Bungin, Burhan, 2001, Analisis Data Penelitian Kualitatif ; Pemahaman Filosofis dan Metodologis Kearah Penguasaan Model Aplikasi, Jakarta, PT. Raja Grafindo Persada Dadang Juliantara, Pembaruan Desa ; Bertumpu Pada Yang Terbawah, Yogyakarta, Pustaka Yogyakarta, 2003

Deddy Mulyana, 2007, Ilmu komunikasi ;

Suatu Pengantar, Bandung, PT. Rosdakarya 
, 1999 ; Nuansa Nuansa

Komunikasi, Meneropong Politik

dan Budaya Komunikasi

Masyarakat Kontemporer, Bandung,

PT. Rosdakarya

Doyle, Paule Johnson. 2004. Teori

Sosiologi Klasik dan Modern,

Jakarta, PT. Rinneka Cipta.

, Pemerintahan Desa

dan Administrasi Desa (Sebuah

Tinjauan), Jakarta, Raja Grafindo

Persada, 2006

Jalaluddin Rakhmat, Psikologi

Komunikasi, Remadja Karya,

Bandung, 1988

Kansil, CST, Pengantar Imu Hukum, Jakarta, Balai Putaka, 2004
Kartini Kartono, Pemimpin dan Kepemimpinan, Jakarta, Rajawali, 2000

Koentjoroningrat, Metode Penelitian, Jakarta, Bina Pustaka, 2006

Soenarto, 2006. 2004, Sistem Sosial Budaya Indonesia, Jember, LKPM, FISIP UNEJ

Soekanto, Soerono, 1999, Sosiologi Suatu Pengantar, Jakarta, CV. Radjawali

Soerjono Soekanto, Kedudukan dan Peranan Kalebun, Jakarta, CV. Rajawali, 2002

Anonim, Undang Undang No.32 Tahun 2004 tentang Pemerintahan Daerah, Yogyakarta, Bintang Cemerlang, 2005 